\title{
Trade liberalization and premature deindustrialization in Colombia
}

Mateo Hoyos López ${ }^{*}$ (D)

*Correspondence:

m.hoyos754@uniandes.edu.co Bogotá Council, Calle 36 \# 28A-41

Office 201, Bogotá, Colombia

\begin{abstract}
This work analyzes the phenomenon of premature deindustrialization for Colombia and for other seven Latin American countries. Through a Koyck transformation model for the Colombian case, and a panel data fixed effects model for the complete sample of eight Latin American countries, this work documents that the fall in the average effective tariff in the region is the main economic explanation of the premature reduction in the manufacturing share. Also, it provides evidence that relates negative performance of manufacturing to foreign investment flows and to Dutch disease. On the other hand, taking into account the importance of manufacturing on productive sophistication and economic development, this work applies product space methodology in order to determine strategic manufacturing sectors for the establishment of a selective industrial policy for the Colombian case. As a result, the sectors that must be encouraged by the Colombian State are manufactured intermediate goods, mainly goods in the chemical industry.
\end{abstract}

Keywords: Deindustrialization, Tariffs, Washington Consensus, Industrial policy, Structural transformation, Colombia, Latin America

JEL Classification: F14, O12, O14, O54

\section{Introduction}

Despite the recent boom of economic growth in Colombia, explained mainly by the period of high prices in commodities of mining and energy, the country is still far from the income of developed countries. In 2014, while USA had a GDP per capita of more than fifty thousand dollars, Colombia presented a GDP per capita of less than eight thousand dollars. ${ }^{1}$ Although there are serious criticisms to the GDP as a measure of well-being, this difference expresses a disturbing contrast that must be studied in detail.

While this divergence between the USA and Colombia is of old date, there are countries that in the last 50 years have managed to close the income gap, leaving behind other developing economies. For example, in 1960 Korea had a GDP per capita smaller than the Colombian, but in 1990 the Asian country was already richer. In 2014, Korean GDP per capita was already over thirty thousand dollars, more than three times the Colombian GDP per capita. The literature says that the set of policies used by the Asian country, which caused this economic "miracle" or late industrialization process, were very

\footnotetext{
${ }^{1}$ Data taken from the World Development Indicators of the World Bank, in constant 2010 US dollars.
}

(c) The Author(s) 2017. This article is distributed under the terms of the Creative Commons Attribution 4.0 International License (http://creativecommons.org/licenses/by/4.0/), which permits unrestricted use, distribution, and reproduction in any medium, provided you give appropriate credit to the original author(s) and the source, provide a link to the Creative Commons license, and indicate if changes were made. 


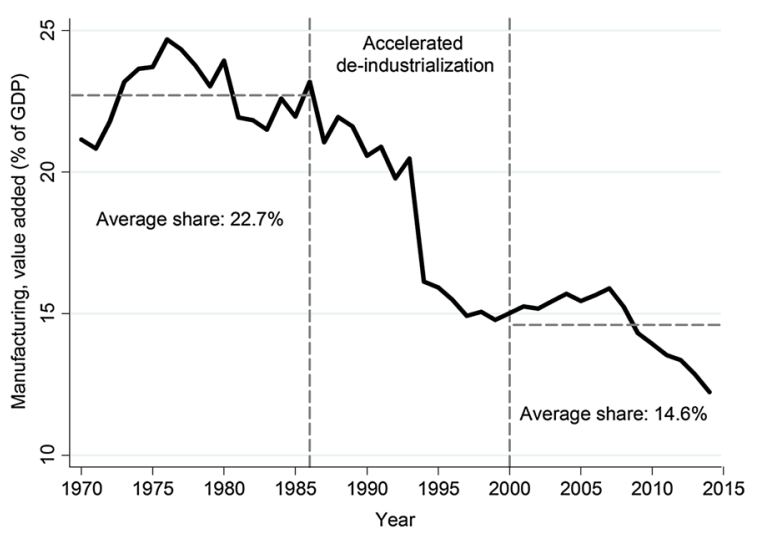

Fig. 1 Colombia: manufacturing share. Source: Author's calculations based on World Bank (2016)

different from Washington Consensus policies, largely based on manufacturing upgrading and characterized by strong intervention of the State (Wade 1990; Amsden 1992; Reinert 2007; Rodrik 2008; Stiglitz et al. 2013).

The world is now attending to deep international economic changes. Countries such as Brazil, Russia, Turkey and Colombia, which were called to be the new engines of global economic growth, have begun to show symptoms of deceleration and crisis. As Rodrik (2015a) says, these countries didn't show a coherent story of economic growth. In other words, those high rates of economic growth in the past decade were generated by the boom of commodities and not because of real productive sophistication. This was not the path followed by countries that achieved the status of developed recently, with the renowned examples of Korea and Japan. According to Rodrik (2015a), most of the emerging economies worldwide are now living a premature deindustrialization phenomenon.

Manufacturing has been a key part in the structural transformation of the economies recently graduated as developed, and it has also been the more stable fountain of economic development in history (Rodrik 2013a). However, in Colombia since 1990 the share of manufacturing has plummeted (Fig. 1). It is worth noting that this impressive fall coincided with the adoption of Washington Consensus policies, ${ }^{2}$ or "Apertura Económica" as it was called within the borders. Almost all the countries of the region share both the fall in the participation of manufacturing and the adoption of Washington Consensus policies.

The fall in manufacturing participation in Colombia is not explained by an absolute fall in manufacturing output (Fig. 2). In fact, Colombian manufacturing output has increased in $68 \%$ in the last 35 years. However, this manufacturing growth has been tiny in comparison with those of successful industrializers. While Colombian manufacturing grew at an average of 1.6\% annually between 1980 and 2015, Korean manufacturing did so at 8.6\%. In the period mentioned, Korean manufacturing output multiplied sixteen times, while the Colombian did not even double. The fall and this difference make important to study in depth the determinants of Colombian manufacturing performance.

${ }^{2}$ This set of policies is going to be explained later. 


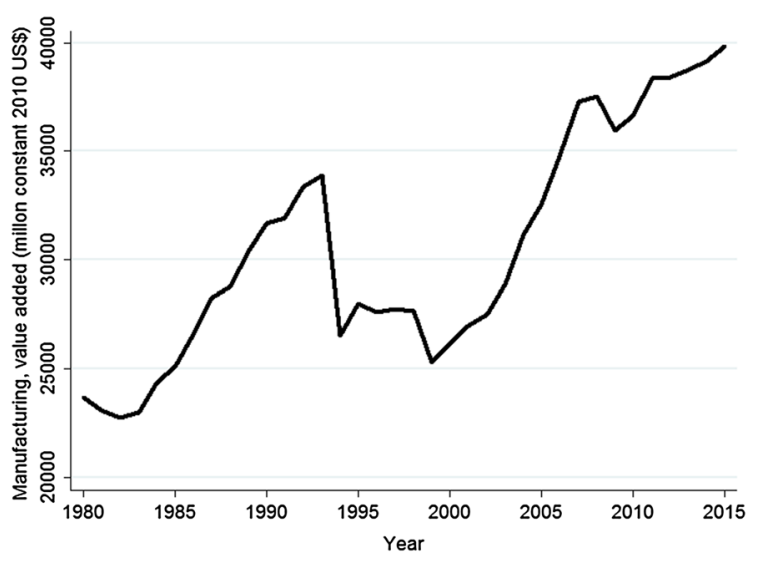

Fig. 2 Colombia: manufacturing output. Source: Author's calculations based on World Bank (2016)

The economic relevance of this work is that it identifies the most important economic explanation of the fall in the manufacturing share in Colombia and the region since the 1990s, and classifies this fall as a premature deindustrialization phenomenon. Likewise, it is also relevant because it advances in the identification of key manufacturing sectors, based on a different theoretical approach to the role of the State in the economy, in order to establish a new industrial policy for the country and to achieve truly structural transformation of the Colombian economy.

In the second part of this work, there is going to be a review of the arguments that support a theory of state intervention for the emergence and consolidation of manufacturing. The third part is an empirical approximation to the causes of deindustrialization in Colombia and in the region. Finally, the fourth part presents an exercise of selective industrial policy, based on the product space methodology (Hausmann and Klinger 2006), in order to establish strategic manufacturing sectors to be promoted by the Colombian State.

\section{The theory of interventionism}

\subsection{Economic development and productive structure}

Unlike neoclassical economics, evolutionary economics established a relation of dependence between economic growth and the productive structure. In particular, these economic theories claimed that economic growth was always accompanied by changes in the productive structure. In other words, economic development, understood as high and stable rates of economic growth, which led underdeveloped countries to converge with the level of income in developed countries, is caused by structural transformation. That is, economic development is the emergence and consolidation of new manufacturing sectors with higher productivities, accompanied by the transference of labor from traditional economic sectors to the new ones.

Economic development is thus conceived as the process of structural transformation of the economy (Rodrik 2013a). This idea means that developed economies are structurally different from developing economies. In the first place, underdeveloped countries are characterized by large gaps of productivity between distinct economic activities, while in developed economies these differences are smaller. In the second place, 
developed countries have a more diversified productive apparatus, while underdeveloped countries are more specialized in some products. ${ }^{3}$ The key point of really reaching economic development, for developing economies to transit into developed ones, resides in the sophistication of products, diversification of production and closing the gap between new and traditional economic sectors ${ }^{4}$ (Rodrik 2013a).

Rodrik (2013a) documents two additional key ideas: First, industrialization and manufacturing exports has been the most trustworthy generators of high rates of economic growth, and second, the most successful economies are not those with less state interventionism. While showing these cases in detail goes beyond the scope of this article, Amsden's work (1992) on Korea and Johnson's work (1982) on Japan reveal how these two countries are examples of successful state intervention policies in the promotion of structural transformation of their economies.

\subsection{Why manufacturing?}

Manufacturing has virtues that make it special in comparison with other economic sectors. Unlike agriculture, which presents diminishing returns of scale in production, manufacturing is an activity with increasing returns. In other words, as manufacturing output increases the cost of an additional unit of production diminishes. This thesis of increasing returns is captured in the so-called Verdoorn law, which is part of the laws about economic growth of Nicholas Kaldor. This law states that as production increases industrial productivity grows, especially because of "more investment in art equipment and learning generated by productive experience" (Ocampo and Martínez 2011, p. 18). Recent work by Marconi et al. (2016) revealed that, between 1990 and 2011, the evidence not only supports Verdoorn law but also fulfills another Kaldor law, according to which the higher the growth of manufacturing, the higher the total economic growth.

Additionally, Rodrik (2013b) affirms that manufacturing presents unconditional convergence. The author proves that companies from a particular manufacturing sector that begin in lower levels of productivity experience faster rates of growth reaching progressively the technological frontier of the sector. Obviously, conditional convergence, which implies favorable policies, is faster, but the shocking result is that convergence exists unconditionally. This characteristic does not appear to be present in other economic sectors, which makes manufacturing special (Rodrik 2013b).

The evidence also suggests that manufacturing is special because it allows countries to achieve the status of developed. In 2014, Felipe, Mehta and Rhee proved that approximately $95 \%$ of developed economies by that time passed through a strong industrialization process. In particular, they documented another important idea for industrialization to really generate development: "achieving a manufacturing employment share of $18-20 \%$ has been almost sufficient and absolutely necessary (in the statistical sense) for achieving high-income status" (Felipe et al. 2014, p. 13). In other words, "peak manufacturing employment shares in excess of $18-20 \%$ strongly predict that an economy is rich; while peak shares below this threshold are near perfect predictors that an economy

\footnotetext{
${ }^{3}$ Colombia, for instance, is highly specialized in banana and flowers.

4 This idea is opposed, in certain sense, to the theory of comparative advantage that has been a key part of the justification of globalization (Rodrik 2013a).
} 
is not rich (i.e., manufacturing employment is necessary for becoming rich)" (Felipe et al. 2014, p. 10).

There are recent voices claiming for a service-led strategy for development. However, there are enough concerns to be skeptical about this path. In the first place, the sectors of tradable services that have been acquiring importance, such as technological ones, do not have the employment potential that manufacturing has. ${ }^{5}$ In the second place, labor absorbed in services is going to non-tradable sectors such as retail trade and housework. However, here comes another difference that reinforces the importance of manufacturing, "partial productivity gains in non-tradable activities are ultimately self-limiting, because individual service activities cannot expand without turning their terms of trade against themselves-pushing down their own prices (and profitability)" (Rodrik 2014).

Increasing returns and unconditional convergence make manufacturing special. ${ }^{6}$ If we add to these two things the employment potential and its tradable characteristic, with the consequent ability to promote the growth and consolidation of a domestic market, manufacturing is still important for structural transformation of developing economies in Latin America.

\subsection{Market failures: the National Champions}

Structural policy reforms in Latin America, between the years 1985 and 1995, were shaped by the Washington Consensus. This concept was keyed by Williamson (1990) and provided ten rules on economic policy. Particularly, it dictated two rules relevant in manufacturing upgrading: total trade liberalization, especially with regard to free entrance of imported manufactured goods, and the proscription of the use of public spending in subsidies and incentives to strategic productive sectors. These two rules were proposed and established in Latin America in contraposition to the economic policy that characterized the previous period, called import substitution industrialization (ISI), condemned as a failure. The new dogma that came into light was "the best industrial policy is not having one" (Ocampo and Martínez 2011).

Two decades after the strict application of the Washington Consensus prescriptions, the results have not been satisfactory. On the one hand, the successes of economies such as Korea, Taiwan, Japan and recently China, the countries with the highest annual rates of economic growth in history, are based on policies different to those of the Washington Consensus (Wade 1990; Amsden 1992; Chang 1994; Reinert 2007; Stiglitz et al. 2013; Rodrik 2013a). Specifically, the role of the state was active in promoting some strategic economic sectors. On the other, the application of the Consensus has resulted in a less dynamic world, with small rates of economic growth compared with the ISI period. According to Ha-Joon Chang (2010), growth in GDP per capita of Latin American countries during ISI averaged 3.1\%, while during the last period averaged $0.5 \%$.

The imposition of this set of neoliberal policies in the globe was accompanied by the establishment of the market failures literature in economics (Stiglitz et al. 2013). The idea that markets by themselves were driving to Pareto-efficient results was discarded.

\footnotetext{
${ }^{5}$ An example of this is that the IT sector in India has shown its failure to develop the Indian economy.

${ }^{6}$ UNCTAD (2016) summarizes all the virtues of manufacturing that have been studied in economics literature. It is worth mentioning that these virtues go beyond those mentioned here.
} 
"By now, there is a rich catalogue of market failures, circumstances in which the markets may, say, produce too little of some commodity or another, and in which industrial policies, ${ }^{7}$ appropriately designed, may improve matters" (Stiglitz et al. 2013, p. 1). Thus, National Champions literature in economics has appeared, referring to firms receiving targeted support from the State with subsidies, soft loans or any other protection method to enhance growth and development perspectives (Aubert et al. 2011).

Which are those failures that justify the selective intervention of the State? In the first place, the most prominent failure is the coordination one (Chang 1994; Hausmann and Rodrik 2006). The coordination failure is related to incomplete markets. Thus, economic benefits of one investment would depend on the realization of other investments. For example, constructing a hotel in a beach would be profitable if someone else decides to build an airport to take people to that beach (Hausmann and Rodrik 2006, p. 7). This kind of situations is frequent in manufacturing upgrading, especially if it is referred to new sectors linked with science and technology. Therefore, a mechanism of ex-ante coordination is justified, and there is where State can come into action.

The second important economic failure is called information spillovers. This failure characterizes the apparition of new economic activities. The first firm to incur in the process of developing a new activity would find whether it is profitable or not. If this firm triumphs in its venture, other firms will follow its path and would enter the market. But if the firm fails, the firm bears the whole economic loss. "Because of this, the private returns from engaging in this type of innovation are lower than the social benefits, and the market incentives for self-discovery are inefficiently low. The typical policy implication is to provide a subsidy in order to bring the private returns in line with the social returns" (Hausmann and Rodrik 2006, p. 8).

The last market failure relevant to this work is that markets by themselves are inefficient with the production and dissemination of knowledge. That is what Stiglitz and Greenwald (2013) have called market failures in the context of a learning economy. First of all, knowledge is in certain way a public good; its usage is non-rivalrous and the marginal cost of another person enjoying knowledge is zero. As it is known, markets by themselves are not efficient providing public goods. Secondly, the process of learning is endogenous: learning is reached as you practice it, as you produce. "But Washington Consensus policies based on neoclassical models that ignore the endogeneity of learning often have consequences that are adverse to learning, and thus to long-term development" (Stiglitz and Greenwald 2013, p. 3). This market failure is especially relevant to the cases of late industrialization. Late industrialization, such as that lived by the Asian tigers, is addressed in learning. In other words, unlike first industrializations such as those of European countries, late industrializations are in essence a process of copy and learning of advanced manufacturing (Amsden 1991).

These three market failures explained before give fundamental to the argument of incipient industry: the creation of rents for the promotion of punctual strategic economic sectors. For that reason, Aubert et al. (2011) establish a model of National Champions relying in the stage of the firm's life. Subsidies for young and innovative firms are

\footnotetext{
${ }^{7}$ Industrial policies refer to state intervention policies in order to potentiate strategic economic sectors. A more detailed definition can be found in the work of Chang (2010).

8 That is what Arrow called learning-by-doing.
} 
justified when rents induce investment in activities that, by their own, firms won't invest in. For mature firms, protection would be useful if it induces investments on expensive innovations that were impossible for the firm to cover, even with credit. The key aspect is to avoid subsidies and protection for firms without incentives to make innovative investments (Aubert et al. 2011, p. 73). Finally, for the authors this analysis leaves another important lesson. Even when protection tools such as tariffs introduce an inefficient delay in the relocation of resources between economic activities, they are cheaper than subsidies, situation extremely important for underdeveloped countries where public budget constraints are the rule (Aubert et al. 2011, p. 75).

\section{Premature deindustrialization in Colombia and the region}

\subsection{Motivation}

Economic development understood as a process of stages predicts that manufacturing will be overtaken by services as the leading economic sector of the economy. Thus, the fall in the manufacturing share in the economy is something normal, which happens when the economy reaches certain point of GDP per capita. This type of deindustrialization is called secular (Rowthorn 1997). By contrast, deindustrialization caused by early incursion of the economy into services, without enough manufacturing development, is called premature (Rodrik 2015b; UNCTAD 2016).

Taking into account this distinction, Clavijo et al. (2012) documented that Colombia was suffering a premature deindustrialization phenomenon. The authors made an empirical exercise in order to determine whether deindustrialization was strictly secular or whether it was premature, related to a Dutch disease phenomenon. In 2012, they concluded, "Colombia is getting trapped in this scheme of early withering of manufacturing, caused by the boom of commodities and exchange appreciation" (Clavijo et al. 2012, p. 80).

Premature deindustrialization is not an exclusive phenomenon of Colombia. Rodrik (2015b) demonstrated that it is common of all developing countries in the world, but especially of Latin American countries. In his work, Rodrik tests both hypotheses of deindustrialization: secular and premature. He concludes that "while technological progress is no doubt a large part of the story behind employment de-industrialization in the advanced countries, in the developing countries trade and globalization likely played a comparatively bigger role" (Rodrik 2015b, p. 5). In conclusion, "these developing countries are turning into service economies without having gone through a proper experience of industrialization" (Rodrik 2015b, p. 3).

The problem of premature deindustrialization, again, is that it doesn't exist in an economic model of truly progress that doesn't require of manufacturing. "Its relative absence in today's developing societies could well be the source of political instability, fragile states, and illiberal politics" (Rodrik 2015b, p. 24).

\subsection{Review of empirical literature and methodology}

\subsubsection{Review of literature}

The most important econometric exercise about deindustrialization in Colombia was made by Clavijo et al. (2012). However, the hypothesis of this earlier work was to prove 
the existence of Dutch disease and not to study the possible relation of Washington Consensus policies with deindustrialization.

The estimation made by Clavijo et al. (2012) consisted in one ordinary least squares (OLS) model and another Koyck model to estimate the impact of growing mining and energy exportations over manufacturing. In the OLS model, justified by cointegration proofs, the authors estimated the short-term impact. On the other hand, the Koyck model introduces the lag of the dependent variable as independent, in order to identify the long-term impact. This work never referred to biases of endogeneity.

Bogliaccini (2013) established an approximation to prove that deindustrialization in Latin America was related to the application of the Washington Consensus. His hypothesis was that trade liberalization, as one central aspect of the Consensus, leads to deindustrialization in some countries of the region such as Argentina, Brazil, Chile, Costa Rica, Mexico, Uruguay and Venezuela. "Import competition, particularly where liberalization happened quickly, caused the bankruptcy of many industrial enterprises. Many of them simply closed down, and those jobs were lost" (Bogliaccini 2013, p. 83).

The data used by Bogliaccini (2013) covered 7 countries with annual data since 19802000. The methodology used by the author was OLS with standard errors corrected with panel data (POLS). This methodology seeks to eliminate the inefficiency, assuming consistency, of the coefficients estimated by POLS, since OLS do not take into account possible contemporaneous correlations of errors (Beck and Katz 1995). That way, Bogliaccini just resolves the inefficiency problem but not the highly possible endogeneity problem.

Finally, Petreski et al. (2015) made an empirical analysis of the deindustrialization for 25 countries of central Europe caused by trade liberalization, making use of the lag of the average tariff as the independent variable. In their conclusions, the authors document that, in general, lower tariffs lead to higher value added in manufacturing through higher imports of inputs in the production process that were nonexistent in the domestic market, or were more expensive than in the international market.

The authors say that "the econometric challenge is that tariffs [rates] are almost always endogenous to the industry value added" (Petreski et al. 2015, p. 8). The theory of endogenous tariffs establishes that "political decisions on tariff rates are reflections of the selfish economic interests of voters, lobbying groups, politicians or other decision makers in trade policy matters" (Mayer 1984, p. 970). Therefore, Petreski et al. (2015) discuss the necessity of finding an instrument for the present tariff rate and define that a good alternative is the lag of the tariff rate. According to them, this instrument is adequate because, in principle, it fulfills the two conditions of (1) relevance, since governments are prevented from abrupt changes in tariffs and (2) exogeneity, since the past tariff is unlikely to be related to contemporary shocks on the value added of manufacturing (Petreski et al. 2015). Moreover, since the signature of GATT in 1994 and the approval of Free Trade Agreements, governments in developing economies have lost decisionmaking power over tariffs, which would indicate that they cannot define these taxes in relation to manufacturing performance or other economic variables of interest (Chang and Andreoni 2016). 


\subsubsection{The logic of the exercise}

The estimation made by Clavijo et al. (2012) established as dependent variable the participation of manufacturing in the economy. In addition to being a more precise indicator of purely manufacturing behavior, the authors justify their choice because the performance of this variable, according to the analysis of Rowthorn (1997), is the one that shows the existence or not of premature deindustrialization. Thus, in this paper, the participation of manufacturing in the economy will be used as the key dependent variable.

Clavijo et al. (2012), including international trade as a percentage of GDP, concluded that trade liberalization had a positive impact over manufacturing performance. Furthermore, they said that such a result made it possible to conclude that the relatively new Free Trade Agreements subscribed by Colombia were a good strategy. In other words, they concluded, using international trade as a percentage of GDP (outcome variable), that trade liberalization (the policy) had a positive impact over manufacturing performance. Unlike Clavijo et al. (2012), Bogliaccini (2013) uses as the key independent variable the index of commercial openness, taken from a series of indicators created by ECLAC in 1999 and updated by Eduardo Lora in 2012.

Referring to the update of the indexes mentioned, Lora stated in 2012:

"The original construction of the indexes was motivated by the absence until that moment of measurements on the progress of the [Washington Consensus] reforms. As argued then, the lack of direct measurements of structural policies prevented adequate evaluating the effects of reforms on economic growth and other variables. The few studies that had tried to analyze the effects of the reforms had used outcome variables such as the foreign trade coefficient of the economy, the size of public expenditure or financial depth rather than policy variables such as tariffs, tax rates or banking reserve coefficients" (Lora 2012, p. 2).

The precise selection of the independent variable is not a minor issue. For the reasons below, the key independent variable of this paper is, directly, the average effective tariff rate. ${ }^{9}$ This is a policy variable (that accounts the evolution of the application of trade liberalization policy) and thus permits to evaluate more precisely the results of the policy. As it is shown in Fig. 3, this variable has had a constant fall in Colombia in the past 25 years. Thus, in this paper trade liberalization is understood as a policy of reduction in tariff rates. ${ }^{10}$

In synthesis, the objective of this empirical exercise is to determine whether trade liberalization (reduction in tariffs) has had a negative impact on Colombian manufacturing performance.

\subsection{Data: sources, countries and period}

The initial data only present information of Colombia from 1970 to 2014 (Additional file 1). The manufacturing share and the other control variables were taken from the data of the World Bank (2016). The average effective tariff rates are taken from a response to a

\footnotetext{
9 This is the simple average effective tariff rate.

10 Trade liberalization is in general terms the elimination or reduction of barriers to free trade in goods between nations. Beyond the reduction of tariffs, it includes the removal of non-tariff barriers, such as rules or natural and geographical constraints, exacerbated by lack of infrastructure, that hinder trade.
} 


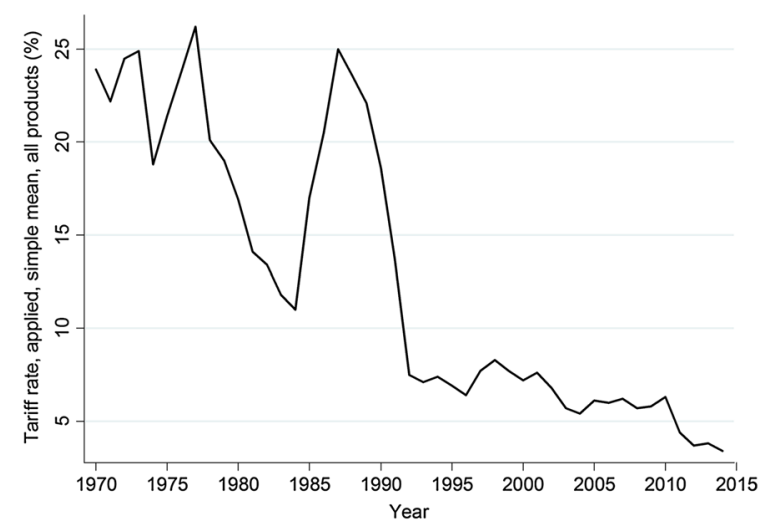

Fig. 3 Average effective tariff rate 1970-2014. Source: National Tax and Customs Office of Colombia (DIAN) (2016)

request sent by the author to the National Tax and Customs Office of Colombia$\operatorname{DIAN}^{11}$ (2016).

The database has only 45 observations, each one of a year from 1970 to 2014. The above information is used to find deindustrialization relations for the Colombian case. However, in order to have a more precise statistical inference, a database for eight countries of the region, which also had reform processes framed in the Washington Consensus, is also used (Additional file 2).

The countries of the database are those of the region with enough and clean information, without important gaps. These countries are Bolivia, Brazil, Chile, Colombia, Costa Rica, Ecuador, Mexico and Uruguay. The database has information from 1985 to 2014. Manufacturing share and the control variables were taken from the data of the World Bank. The average effective tariff rates were taken from the bank of data about international trade of the World Bank (2016) and were complemented with information from Lora's work (2012). Figure 4 shows the share of manufacturing, and Fig. 5 shows the average tariff rates. ${ }^{12}$ Both figures show that manufacturing share and average effective tariff have been falling steadily since 1990 for all the countries in the sample.

The Brazilian case is interesting. While manufacturing accounted for more than $30 \%$ of GDP in 1985, above all other countries, by 2014 manufacturing accounted under 11\% of GDP, below the other countries. In parallel, the average effective tariff in 1985 for this country was slightly more than $80 \%$ and fell to about 13\% in 2014 .

The Colombian case also presents elements to note. After Brazil, Colombia is the country where manufacturing has a smaller participation in the GDP for 2014. On the other hand, between 1985 and 1990, the country raised the tariffs after a decrease in the previous lustrum. However, as soon as the "Apertura Económica ${ }^{13}$ " was undertaken, the fall in tariffs coincides with the most dramatic drop in manufacturing participation. Likewise, Colombia's average effective tariff for 2014 is the lowest in the sample. Today,

\footnotetext{
${ }^{11}$ DIAN for its meaning in Spanish.

12 These figures only show information for four countries to be graphically clear.

13 That was the name of Colombia's structural reforms under the policies of the Washington Consensus.
} 


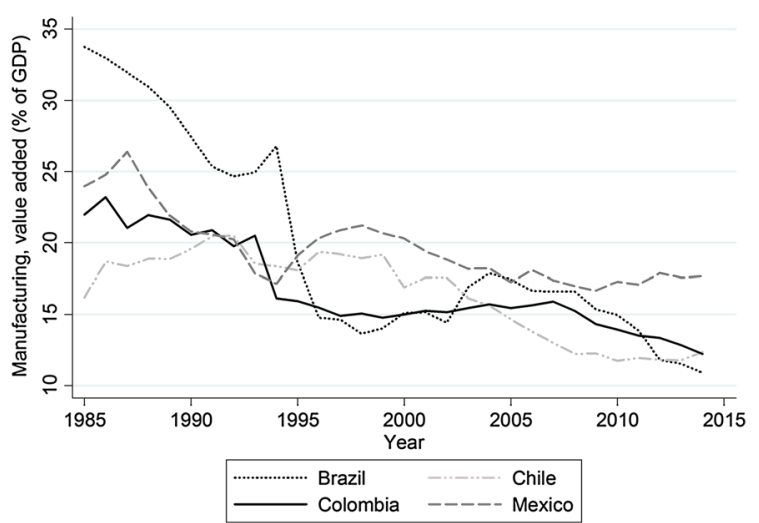

Fig. 4 Share of manufacturing (\% of GDP). Source: Own calculations based on data from the World Bank (2016)

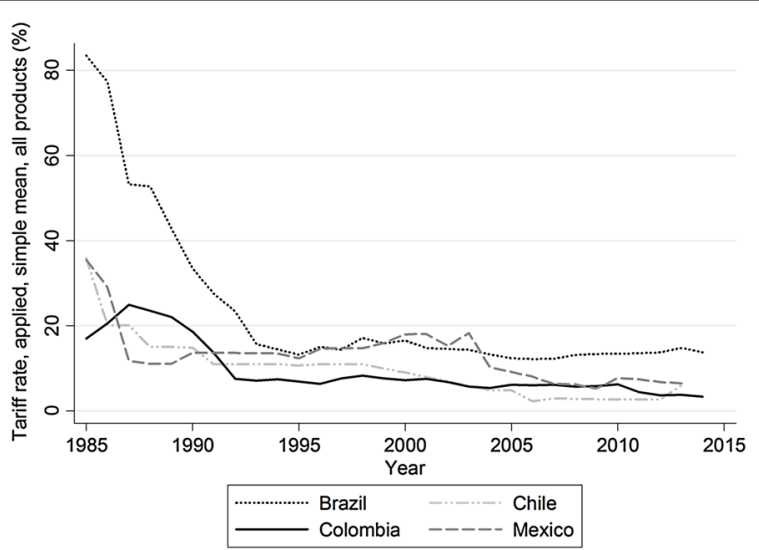

Fig. 5 Average effective tariffs. Source: Own calculations based on data from the World Bank (2016)

Colombia is the Latin American economy more open to international trade, in the sense that it has the lowest effective tariff.

\subsection{Methodology}

For the Colombian case, the models used are an OLS and a Koyck transformation model. The OLS estimation looks for establishing a short-term relation between the variables. It is important to make some clarifications about the estimation by OLS. There is a danger of having a spurious regression (the database is a time series). The series of manufacturing share are not stationary, the same as the series of average effective tariff. Thus, a regression like the one that arises, with two non-stationary series, only makes sense if the following conditions are met: (1) the series have a unit root of order one and (2) the series are cointegrated, in the sense that they have a long-term relationship (Montero 2013). ${ }^{14}$

\footnotetext{
${ }^{14}$ In Appendix 1, the respective tests of stationarity and cointegration could be found. On the other hand, it is important to mention that the proposed OLS model, and the absence of a valid instrument, impedes controlling the endogeneity of tariffs in this estimation.
} 
The Koyck transformation model is the name of an infinite distributed lag model (Parker 2015). It is the geometric form of a model that stipulates that the dependent variable is determined by contemporaneous independent variables and all their lags. This model is useful for this exercise, since the effect of a change in the average effective tariff over the manufacturing share is expected to be dynamic and time-delayed, thus allowing to capture the long-term impact of a change in the independent variables over the dependent. The inclusion of all the lags of the independent variables makes possible to transform the model into a reduced version that only includes the first lag of the dependent variable. However, this comes with a problem. The first lag of the dependent variable is, by construction, correlated with the lag of the error term, and thus, the estimation lacks consistency.

Equation (1) refers to the OLS model to be estimated:

$$
\begin{aligned}
\frac{\text { manufacturing }}{G D P}= & \beta_{0}+\beta_{1} A E T_{t}+\beta_{2}\left(\frac{M E \text { exports }}{\text { total exports }}\right)_{t} \\
& +\beta_{3}(G D P \text { per capita })_{t}+\beta_{4} X_{t}+u_{t}
\end{aligned}
$$

Manufacturing share is going to be estimated with the average effective tariff ( $A E T)$ and other variables of interest. The model includes the participation of mining and energy exports (ME exports) over the total, to avoid bias for possible Dutch disease. In addition, GDP per capita is included to test the hypothesis of secular deindustrialization, that is, manufacturing loses participation, opening the way to services, as income grows. $X$ refers to the rest of the control variables of the model. The first of these is the volume of international trade as a percentage of GDP, to observe possible effects of market spreading over manufacturing performance. And the other control variable is the share of foreign direct investment as a percentage of GDP. The $u$ is the error term.

Equation (2), including the same variables as in Eq. (1) and the lagged manufacturing share, specifies the Koyck transformation model:

$$
\begin{aligned}
\frac{\text { manufacturing }}{G D P}= & \delta_{0}+\emptyset \frac{\text { manufacturing }}{G D P}+\delta_{1} A E T_{t} \\
& +\delta_{2}\left(\frac{M E \text { exports }}{\text { total exports }}\right)_{t}+\delta_{3}(G D P \text { per capita })_{t}+\delta_{4} X_{t}+v_{t}
\end{aligned}
$$

The delta coefficients represent the short-term impact of the independent variables on the dependent variable. And $v$ refers to the error term.

The long-run multiplier effect of independent variables over the dependent variable, which is proper of the Koyck model, is defined as follows, where $s$ represents the independent variables:

$$
L R M=\frac{\delta_{s}}{1-\emptyset}
$$

To avoid the problem of inconsistency in the Koyck transformation, caused by the correlation between the lag of the dependent variable and the error term, Rosiak-Lada and Wójcik (2006) propose to instrument the lagged dependent variable with the first lags of the independent variables, since these variables are in principle not correlated with their contemporary errors. 
On the other hand, for the estimation with the sample of eight countries, an OLS regression will be made and, in addition, the data panel methodology will be used. By having a panel, with several countries, unobserved characteristics peculiar to the countries can be eliminated, which for the manufacturing case of interest may refer to domestic policies not captured by the data or to the attitude of governments regarding domestic manufacturing, and which would have differential effects over manufacturing performance of the countries.

Equation (4) refers to the OLS model:

$$
\begin{aligned}
\frac{\text { manufacturing }}{G D P}= & \beta_{0}+\beta_{1} A E T_{i t}+\beta_{2}\left(\frac{M E \text { exports }}{\text { total exports }}\right)_{i t} \\
& +\beta_{3}(G D P \text { per capita })_{i t}+\beta_{4} X_{i t}+u_{i t}
\end{aligned}
$$

The estimation is essentially the same as that of the Colombian case, although an additional variable is also included, which is the real exchange rate to the US dollar, also linked to the Dutch disease phenomenon. The variables are the same as in the first exercise, but now we have another index $i$ that refers to countries.

For the estimation with panel methodology, it is necessary to determine whether unobserved characteristics, referred previously as domestic policies or attitude of the government with regard to national production, are fixed or random effects. In particular, these are expected to be fixed effects, because domestic policies could be correlated with trade volume, among others. It would be the same with the governmental attitude toward domestic manufacturing. On the other hand, independent variables of the basic model, which contemplate the different hypotheses that have been handled on deindustrialization, are included.

Finally, the panel model to be estimated is one of fixed effects, as it appears in Eq. (5). ${ }^{15}$

$$
\begin{aligned}
\frac{\text { manufacturing }}{G D P}-\overline{\text { manufacturing }_{i t}}= & \beta_{0}+\beta_{1}\left(A E T_{i t}-\overline{A E T}_{i}\right) \\
& +\beta_{2}\left(\frac{M E \text { exports }}{\text { total exports }_{i t}}-\frac{\overline{\text { ME exports }}}{\text { total exports }_{i}}\right) \\
& +\beta_{3}\left(G D P p c_{i t}-\overline{G D P p c}_{i}\right) \\
& +\beta_{4}\left(X_{i t}-\bar{X}_{i}\right)+u_{i t}-\bar{u}_{i}
\end{aligned}
$$

The within fixed effects model consists of controlling the estimation for possible unobservable effects of each country. This is done, as seen in Eq. (5), by subtracting the mean for each variable in the estimate. The variables are the same as the previous models. Also, taking into account what Petreski et al. (2015) said, the average contemporary tariff will be instrumented with its lag, to avoid bias for double causality. With only one instrument, it will only be possible to test its validity but not its exogeneity. ${ }^{16}$ Even so, the proposed model is interesting to establish relations between the variables of interest.

\footnotetext{
${ }^{15}$ In Appendix 2, the proof that justifies that the correct estimate is by fixed and non-random effects could be found. In particular, the fixed effects methodology used here is within.

${ }^{16}$ In order to prove the exogeneity of the instruments, the model must be overidentified. However, because of the limitation of the data, it is not possible to use another instrument to control endogeneity problem of tariffs.
} 
In Appendix 3, you can find some robustness checks. First, it is decided to include a fourth model, which more accurately captures the factor endowment of countries and its possible impact over manufacturing performance. Despite that most of the rich countries have achieved this status based on a strong industrial productive apparatus, the fact is that countries are different, they do not have the same resources, and therefore, neither should have the same manufacturing participation. In this sense, the factor endowment of a country is important in determining the performance of manufacturing. In the literature, the participation of exports of basic (primary), agricultural and mining goods is used as a proxy for factor endowment. Therefore, since in the initial exercise the participation of mining and energy exports is one of the variables used, for this robustness test this variable is eliminated and only the participation of basic exports is counted. The hypothesis behind this exercise assumes that if the country deindustrialized because of its natural resources endowment, the participation of basic exports must be significant and the average effective tariff must have a smaller effect over manufacturing.

The second robustness exercise uses the average most favored nation tariff to instrument the average effective tariff. Although data for this exercise are more limited (most favored nation tariff information is scarcer), this check is done to tackle the possibility of causality between future expected manufacturing performance and present tariff rates as a policy response. Most favored nation tariff refers to "what countries promise to impose on imports from other members of the WTO, unless the country is part of a preferential trade agreement (such as a free trade area or customs union). This means that, in practice, MFN rates are the highest (most restrictive) that WTO members charge one another" (World Bank 2010). By definition, these tariff rates are higher than the average effective tariff rates and are less exposed to policy discretion. (They are part of international agreements, not changeable as manufacturing plummets.)

The third robustness check is to include two additional explanatory variables that have been identified as important explaining manufacturing performance. According to Petreski et al. (2015), domestic credit to the private sector as a percentage of GDP and terms of trade (the relative prices of exports and imports) are negatively related to manufacturing performance. Thus, these two variables are included to evaluate whether this inclusion changes previous results.

\subsection{Results and conclusions}

Table 1 shows the results for the Colombian model with the OLS model and the Koyck transformation model.

As expected, the OLS estimation shows that the coefficient of AET is positive. In particular, a drop of one percentage point of AET is related to a drop in the share of manufacturing output of 0.24 percentage points. On the other hand, an increase of one percentage point in the share of mining energy exports is linked to a fall of 0.11 percentage points in the share of manufacturing output. Interestingly, the coefficient associated with international trade was negative. Finally, neither GDP per capita nor FDI as a percentage of GDP were significant in estimating the share of manufacturing output.

The Koyck model ratifies the significance of AET and mining and energy exports on manufacturing share. By contrast, international trade as a percentage of GDP loses its significance, thus showing that the relationship between the variables is not a strong one. 
Table 1 Results for the Colombian case

\begin{tabular}{lll}
\hline Variables & $\begin{array}{l}(\mathbf{1}) \text { OLS } \\
\text { Manufacturing/GDP }\end{array}$ & $\begin{array}{l}\text { (2) Koyck } \\
\text { Manufacturing/GDP }\end{array}$ \\
\hline AET & $0.241^{* * *}$ & $0.153^{* * *}$ \\
ME exports/total exports & $(0.0481)$ & $(0.0454)$ \\
& $-0.116^{* * *}$ & $-0.0694^{* *}$ \\
GDP per capita & $(0.0298)$ & $(0.0266)$ \\
& 0.00155 & 0.00112 \\
International trade/GDP & $(0.000992)$ & $(0.0009)$ \\
& $-0.167^{* *}$ & -0.0405 \\
FDI/GDP & $(0.0823)$ & $(0.0731)$ \\
& -0.302 & -0.0230 \\
Lagged manuf/GDP (instrumented) & $(0.213)$ & $(0.186)$ \\
& & $0.609^{* * *}$ \\
LRM AET & & $(0.149)$ \\
LRM ME exports/total exports & & 0.3913 \\
Constant & & -0.1774 \\
Observations & $20.65^{* * *}$ & 5.338 \\
$R^{2}$ & $(3.248)$ & $(4.874)$ \\
Ramsey reset test & 45 & 43 \\
\hline
\end{tabular}

Standard errors in parenthesis

${ }^{* * *} p<0.01 ;{ }^{* *} p<0.05 ;{ }^{*} p<0.1$

The short-term effect of a drop of one percentage point of the AET is a drop of 0.15 percentage points of the manufacturing share. Additionally, as allowed by the Koyck transformation, the long-term effect of a drop of one percentage point of the AET is a drop of 0.39 percentage points on the manufacturing share.

Even though these results are suggestive, the OLS and Koyck models don't tackle the problem of endogeneity. In that sense, arising conclusions based on the statistics presented on Table 1 could possibly be mistaken. The use of panel data econometrics allows to tackle endogeneity and to extract correct conclusions. The results of the estimation for the sample of countries are presented in Table 2. Results are presented for an OLS model, a panel model with fixed effects and a panel model with fixed effects and with the average tariff instrumented with its lag (Petreski et al. 2015).

According to the results of the non-instrumented model, the largest impact on the variable of interest, unlike the Colombian case, is now due to FDI, as an increase of one percentage point is linked to a fall of 0.28 percentage points of the share of manufacturing. Likewise, a fall of one percentage point in the AET is related to a fall of 0.17 percentage points in the share of manufacturing. The increase of one percentage point in the share of mining and energy exports is associated with a much lower fall of 0.05 percentage points in the share of manufacturing. Likewise, the appreciation of the currency is also related to deindustrialization. On the contrary, an increase of 1.000 USD in GDP per capita is related to a drop of 1.26 percentage points of manufacturing. Finally, international trade has no statistically effect on manufacturing performance.

By instrumenting the average effective tariff with its lag, to control possible endogeneity, the above results are reaffirmed. The alleged effect of a drop in the AET over manufacturing increases, as now a percentage point fall in the tariff is related to a fall of 0.21 
Table 2 Results for the panel

\begin{tabular}{|c|c|c|c|}
\hline Variables & $\begin{array}{l}\text { (1) } \\
\text { OLS } \\
\text { Manufacturing/GDP }\end{array}$ & $\begin{array}{l}\text { (2) } \\
\text { Within } \\
\text { Manufacturing/GDP }\end{array}$ & $\begin{array}{l}(3)^{\mathrm{a}} \\
\text { Within with IV } \\
\text { Manufacturing/GDP }\end{array}$ \\
\hline AET & $\begin{array}{l}0.200^{* * *} \\
(0.0212)\end{array}$ & $\begin{array}{l}0.172^{* * *} \\
(0.0210)\end{array}$ & $\begin{array}{l}0.219^{* * *} \\
(0.0255)\end{array}$ \\
\hline ME exports/total exports & $\begin{array}{l}-0.0690^{* * *} \\
(0.00923)\end{array}$ & $\begin{array}{l}-0.0501^{* * *} \\
(0.0189)\end{array}$ & $\begin{array}{l}-0.0425^{* * *} \\
(0.0185)\end{array}$ \\
\hline GDP per capita & $\begin{array}{l}-0.000252^{* *} \\
(0.000105)\end{array}$ & $\begin{array}{l}-0.00126^{* * *} \\
(0.000264)\end{array}$ & $\begin{array}{l}-0.000770^{* * *} \\
(0.000270)\end{array}$ \\
\hline International trade/GDP & $\begin{array}{l}0.0509^{* * *} \\
(0.0116)\end{array}$ & $\begin{array}{l}-0.00874 \\
(0.0219)\end{array}$ & $\begin{array}{l}-0.0216 \\
(0.0211)\end{array}$ \\
\hline FDI/GDP & $\begin{array}{l}-0.424^{* * *} \\
(0.0951)\end{array}$ & $\begin{array}{l}-0.284^{* *} \\
(0.112)\end{array}$ & $\begin{array}{l}-0.242^{* *} \\
(0.103)\end{array}$ \\
\hline Real exchange rate & $\begin{array}{l}-0.0188^{* *} \\
(0.00751)\end{array}$ & $\begin{array}{l}-0.0196^{* * *} \\
(0.00732)\end{array}$ & $\begin{array}{l}-0.0852^{* * *} \\
(0.0157)\end{array}$ \\
\hline Constant & $\begin{array}{l}19.51^{* * *} \\
(1.091)\end{array}$ & $\begin{array}{l}26.33^{* * *} \\
(1.424)\end{array}$ & $\begin{array}{l}29.83^{* * *} \\
(1.722)\end{array}$ \\
\hline Observations & 237 & 237 & 229 \\
\hline$R^{2}$ & 0.530 & 0.560 & \\
\hline Countries & 8 & 8 & 8 \\
\hline \multicolumn{4}{|c|}{${ }^{* * *} p<0.01 ;{ }^{* *} p<0.05 ;{ }^{*} p<0.1$} \\
\hline
\end{tabular}

percentage points in the share of manufacturing. With the instrument, the incidence of FDI on industrial performance falls, since now with an increase of one percentage point in the first, the second falls by 0.24 percentage points. On the other hand, the evidence is consistent again with the Dutch disease hypothesis, since the coefficient for mining and energy exports remains statistically negative, although lower. The same happens with the real exchange rate, which reaffirms that the appreciation of the currency has affected manufacturing, although in a smaller amount with respect to the other variables. GDP per capita remains relevant.

Although results above are essentially the same as the individual results for Colombia, the FDI variable now plays a key role in explaining premature deindustrialization. Now, such a result is not at all strange. In fact, approximately $50 \%$ of such investment in Colombia has been directed to the mining and energy sector, which in turn explains the boom in the sector's exports. The impact of the export variable is much lower in the panel, since some countries in the region do not have natural resources as Colombia does. For example, mining and energy exports in Uruguay and Costa Rica do not exceed an average participation of $2 \%$ for the study period. This may also explain why the variable FDI becomes more relevant, since, in fact, the countries of the last example have the largest shares of FDI in the sample, together with Chile.

In summary, the evidence is in line with the Dutch disease hypothesis. Likewise, the data provide evidence in support of the hypothesis that the loss of manufacturing participation is also due to a secular process, since GDP per capita showed significance. However, in absolute terms the impact of GDP per capita remains the smallest of all the significant control variables. For the sample of countries, FDI is also related to the 
manufacturing share decrease. Finally, the evidence is consistent with the hypothesis that the political definition of reducing the AET has affected the manufacturing share in the region. It is worth noting that the greatest impact in absolute terms on manufacturing performance is due to this variable. That is to say, deindustrialization is explained to a greater extent by trade liberalization (fall in the AET) than by the Dutch disease and a secular process, which is also in line with that affirmed by Rodrik (2015b). Results of the robustness checks in Appendix 3 ratify the validity of these conclusions.

In conclusion, the paper documents a positive relationship between tariffs and manufacturing performance. It also documents a negative relationship between FDI and manufacturing performance, which may be explained by the fact that investment in the region has gone to the mining energy sector, causing Dutch disease as observed in the coefficient of mining and energy exports. Likewise, this negative statistical relationship can be also attributed to the destination of FDI into non-tradable sectors (construction and services, for example) that has made manufacturing relatively less profitable (Bárcena 2015). Likewise, GDP per capita, as a proxy for the hypothesis of secular deindustrialization, is relevant to the sample of countries, although less important in absolute terms. Therefore, because the main economic explanations of the fall in manufacturing participation are, in its order, trade liberalization, FDI, the surge of mining and energy exports and not the growth in the GDP per capita, Latin America has lived a premature deindustrialization phenomenon.

\section{Industrial policy in practice}

We have, on the one hand, that the region has deindustrialized because of the application of the policies of the Washington Consensus. On the other hand, we have that the countries that have reached the status of developed in recent times applied policies of strong state intervention. Moreover, we also became aware that state intervention is justified because of the existence of market failures. Those market failures revised block structural change in economies, preventing the emergence of economic sectors that, over time and learning, could be highly profitable. Thus, the objective of this part of the work is to determine the strategic sectors, only for the Colombian case, that should be object of state support (either subsidies, protection or any type of tool in Appendix 4). For that, this work uses the methodology developed by Hausmann and Klinger (2006) called product space. This methodology consists in evaluating each product in three aspects: sophistication, distance from the current basket of production and connections with more sophisticated products.

With world trade data for 2005, Hausmann and Klinger made the proposed exercise for Colombia. However, they included all kinds of products, so the analysis determined that the "best" products were essentially agricultural and natural resources. This situation is contrary to the thesis of this work. On the other hand, from 2005 to 2014, which is the year of the data of this work, the basket of Colombian production has changed. Particularly, the mining sector soared from 2005 to 2010, due to the boom of commodities that affected the Colombian economy. Moreover, manufacturing was also restructured, as the subsectors that assumed the leading role were closely linked to the mining sector. Manufacturing has grown in absolute terms in the last years only because activities such as oil refining have grown dramatically. Similarly, in the last decade there have 
been major economic changes in the world, which also affects product distances and sophistication (economic performance in China, for example). The analysis is even more valid in a context of premature deindustrialization that makes urgent a rethinking of Colombian industrial policies.

\subsection{Methodology of product space}

This methodology consists on the elaboration of three indicators, which allow to evaluate different manufacturing subsectors to determine whether they can be classified as strategic or not. The three indicators are sophistication (PRODY), distance from static comparative advantage (density) and strategic value.

The first indicator, of sophistication, is taken from an article by Hausmann et al. (2006) entitled "What you export matters."

The concept is as follows. First, you have the total exports of a country:

$$
X_{j}=\sum_{i} x_{j i}
$$

where $j$ refers to countries, $i$ refers to products, $X$ represents total exports and $x$ the exports per product.

With this in mind, the level of sophistication associated with each product in the export basket is, as the authors call it, PRODY:

$$
\operatorname{PRODY}_{i}=\sum_{j} \frac{\left(x_{j i} / X_{j}\right)}{\sum_{j}\left(x_{j i} / X_{j}\right)} Y_{j}
$$

where $Y_{j}$ is GDP per capita of the country $j$.

" $P R O D Y$ is an outcome-based measure of sophistication: if a product is mostly produced by rich countries, then it is revealed to be a 'rich', or sophisticated, product" (World Bank 2013), with a high value of PRODY. Thus, if the PRODY of a product is 50 thousand dollars, it is a product with a high level of sophistication, since it is associated with a per capita income like that of the richest countries in the world.

Based on this indicator, Hausmann et al. (2006) elaborate an additional one, which seeks to capture the sophistication of the entire export basket. Subsequently, the authors find that the countries converge to the level of sophistication (implicit income) of their export basket. Thus, they demonstrate that current export basket is an excellent predictor of future growth. In particular, they documented that there are products associated with higher-income countries and products from lower-income countries. That is, the authors capture the fact that developed countries produce different things from underdeveloped countries (Hausmann et al. 2006).

Moving from the current basket of production to a more sophisticated, one requires changes in factor endowments and the production frontier. In other words, entering a new branch of production is difficult as it requires skilled people and, certainly, new inputs. The authors argue that the inputs required for one product are imperfect substitutes of the inputs required for another product. Therefore, to capture this characteristic, the authors create a measure that captures the proximity or distance of the products. This measure is especially important so that the process of structural transformation, as 
a governmental challenge to comparative advantage, does not generate high costs and dramatic leaps (Lin and Chang 2009).

To capture this distance, Hausmann and Klinger (2006) propose the second indicator. The second indicator is the density or distance of a product from the export basket at any given time. Their proposed measurement is one of revealed distance. In this way, the authors state that if two products are close then the probability of both having comparative advantage in a country is also high.

To construct the density indicator, they begin producing a distance indicator $\varphi_{i k}$ between two concrete products. ${ }^{17}$ This distance between product $i$ and product $k$, called proximity, is defined:

$$
\begin{aligned}
& \varphi_{i k}=\min \left\{P\left(x_{i} \mid x_{k}\right), P\left(x_{k} \mid x_{i}\right)\right\} \\
& x_{i j}= \begin{cases}1 & \text { if } \mathrm{RCA}_{i j}>1 \\
0 & \text { on the contrary }\end{cases}
\end{aligned}
$$

The counter $i$ refers to any product, $k$ is also counter of another product and $j$ again refers to countries. $R C A$ means revealed comparative advantage. This means that for constructing the distance between a pair of products, the revealed comparative advantage information of all countries in the sample is used to make a minimum between conditional probabilities.

From the distance, the authors go on to elaborate the density indicator. This indicator is the sum of all the roads (distances) that lead to the product in which the country is present from a product in which it has comparative advantage, divided the sum of all distances that lead to the product in question. This measure varies from 0 to 1 , where a value close to 1 means that the near products present in greater amount comparative advantage in the country in question; in other words, the product is very close to the export basket.

$$
\text { density }_{i j}=\left(\frac{\sum_{k} \varphi_{i k} x_{k j}}{\sum_{k} \varphi_{i k}}\right)
$$

The authors prove that this measure is significant predicting how will be the productive structure of a country in the future. By means of probit and OLS regressions, the authors show that density is always significant predicting future comparative advantage (dummy of 1 or 0 ). Countries jump to products with greater density, that is, closer to their current export basket.

Finally, there is a third dilemma. Having two products as closely and with equal sophistication, it is preferable to jump to one in which the possibilities of sophisticating production are greater. Therefore, the authors elaborate the aggregate density indicator, which seeks to estimate how well the production basket is connected with new opportunities of sophistication. Given the products that a country currently produces, this aggregate density can be measured as the value of the weighted distance of all the

\footnotetext{
17 To the extent that the value of the proximity or distance indicator for two specific products approaches 1 , this means that these products are close, that is, there is a high probability that countries produce both products with a comparative advantage.
} 
products it could potentially produce and its value of sophistication (Hausmann and Klinger 2006).

$$
\text { aggregate density } j=\sum_{i} \sum_{k}\left[\frac{\varphi_{i k}}{\sum_{i} \varphi_{i k}}\left(1-x_{j k}\right) x_{j i} P R O D Y_{k}\right]
$$

Hausmann and Klinger (2006) prove that the aggregate density is statistically significant predicting the sophistication of the productive apparatus in the future. Thus, aggregate density, as a measure of how well connected is the basket of production of a country, conditions the process of structural transformation of a country.

In order to effectively measure whether jumping to a particular product opens new and better possibilities to continue ascending in the process of structural transformation, the change in the aggregate density of including the product in the export basket must be calculated. This change is called strategic value and is shown in Eq. 12 (Hausmann and Klinger 2006).

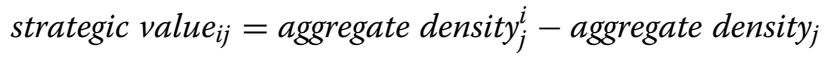

where aggregate density ${ }_{j}^{i}$ is the value that this indicator takes when product $i$ becomes part of the export basket, that is, when product $i$ is now produced in the country with revealed comparative advantage. This indicator captures how the sophisticated connections of the export basket changes when product $i$ becomes part of the basket.

\subsection{Information and database}

For the construction of indicators of PRODY, density and strategic value, United Nations COMTRADE database will be used with information of 2014. This database presents information on 770 products at a 4-digit level, in SITC (Standard International Trade Classification), in its revision number 2. It also presents information from 116 countries. Thus, each observation indicates the total exports by product and country in 2014 . Finally, for the calculations required, the GDP per capita data of the World Bank is added to the base (Additional file 3).

The practical exercise consists of the calculation of the three proposed indicators for each product (or subsector). Subsequently, these three indicators are weighted, giving a value of $33 \%$ to each of them. Thus, in the end the industrial sectors that in such weighting represent a better alternative for the Colombian productive specialization will be obtained. The weighting of these coefficients is justified to the extent that each one of the characteristics captured by them is fundamental in a successful process of structural transformation.

\subsection{Results and conclusions}

First of all, we proceed to calculate the values of sophistication of the products. It is important to clarify that this measure, unlike the other two indicators, is the same for all countries (value per product). The other indicators, as will be seen below, depend on each country and each product. Next, we present the 10 least sophisticated products in the world (Table 3), as well as the 10 most sophisticated (Table 4). 
Table 3 Ten less sophisticated products. Source: Author's calculations

\begin{tabular}{llr}
\hline Product & Code & PRODY \\
\hline Minerals and concentrates of uranium and thorium & 2860 & 442.23 \\
Fabric, woven of regenerated textile materials & 6535 & 568.73 \\
Fine cotton fibers & 2632 & 775.30 \\
Fabrics, of jute fibers or other textile materials & 6545 & 795.88 \\
Sesame seeds & 2225 & 1007.77 \\
Carpets and rugs & 6592 & 1013.36 \\
Tin minerals and their concentrates & 2876 & 1148.58 \\
Jute, other textile fibers, unworked, processed but not spun & 2640 & 1186.76 \\
Tobacco, totally or partially stripped & 1212 & 1200.32 \\
Carded or combed cotton & 2634 & 1549.33 \\
\hline
\end{tabular}

Table 4 Ten most sophisticated products. Source: Author's calculations

\begin{tabular}{lll}
\hline Product & Code & PRODY \\
\hline Amide function compounds, excluding urea & 5147 & $50,477.02$ \\
Sulfonamides & 5157 & $50,092.77$ \\
Petroleum gases and other gaseous hydrocarbons, liquefied & 3413 & $50,069.26$ \\
Natural hormones or reproduced by synthesis, in bulk & 5415 & $49,248.36$ \\
Animal skins, unkempt & 2120 & $46,320.02$ \\
Mechanical wood pulp & 2512 & $44,517.05$ \\
Glucosides, glands, antisera, vaccines and similar products & 5416 & $43,439.2$ \\
Non-mechanical or electrical instruments for physical analysis & 8744 & $42,053.92$ \\
Printing and writing paper, in rolls or sheets & 6412 & $40,860.14$ \\
Parts, unspecified of machines & 7259 & $40,602.95$
\end{tabular}

It is worth mentioning that in Tables 3 and 4 there are all kinds of products, and not only manufactured goods. However, this is done on purpose, since it is possible to show that less sophisticated products are largely associated with primary, agricultural and natural resource products. The less sophisticated product is uranium mineral, as it is associated with a GDP per capita of 442 USD per year. In these unsophisticated products, we can also find cotton, tobacco, among others.

On the other hand, in Table 4, it is possible to observe that the most sophisticated products are all manufactured and of high technical complexity. For example, chemicals, which have by first code number five, are the most sophisticated. Amide function compounds, used as solvents in multiple industrial branches, are the most sophisticated products, as they are associated with a per capita income level of 50,477 USD per year.

It is important to mention an additional feature of the PRODY indicator, evidenced in the data. As this is a measure of revealed sophistication, associated with the real income of the countries, it is possible to find that products such as animal skins have a high sophisticated value. This is due to the fact that animal skins are exported in northern Europe, where per capita income is high. This is not problematic, but it is important to keep in mind. 
Table 5 shows the products in which Colombia has an exporting power. For example, Colombia has a share of flower exports that is 40 times greater than the average share of flowers of all countries. As can be seen, the three most representative products of the country are very low sophisticated products (low associated income). It is worth mentioning that flowers, Colombian's most representative product, have an associated per capita income of only 6424 USD per year. In addition, it is possible to see that the Colombian export basket is concentrated in natural resources: coke, coal, oil, bananas and flowers. This situation ratifies the necessity to establish a state interventionist industrial policy.

On the way to the second indicator, density, the distance between each pair of products of the 770 of the sample is established. It is important to remember that a high density (closer to one) means that two products are generally produced with revealed comparative advantage in the same countries. Table 6 shows an example of the distances for certain products, in order to have a concrete approximation to the measurement.

As it is shown in Table 6, the product closest to the flowers is the cotton seeds because the distance is 0.234 , the highest of the sample. The vehicles are far from the flowers, since the distance is 0.071 . On the other hand, the product closest to vehicles is the chemical wood pulp. Also, electric locomotives are close to the vehicles. Pianos, for example, are closer to flowers than to vehicles. This, which at first sight is curious to say the least, is due to the indicator adopted, which is a measure of revealed distance, which implies proximity in practice, given the world trade, and not technical proximity.

Table 5 Ten products in which Colombia has exporting power. Source: Author's calculations

\begin{tabular}{llrr}
\hline Code & Product & PRODY & RCA \\
\hline 2927 & Cut flowers and foliage & 6424.73 & 40.14 \\
711 & Green coffee, toasted; Coffee substitutes containing coffee & 2886.23 & 29.07 \\
573 & Bananas, fresh or dried & 7025.28 & 24.35 \\
3222 & Other coal, not agglomerated & $19,624.21$ & 20.29 \\
3232 & Coke and semi-coke of coal, lignite or peat; retort carbon & 3309.11 & 17.63 \\
5835 & Copolymers of vinyl chloride and vinyl acetate & $21,474.97$ & 14.30 \\
3330 & Crude oil and oils obtained from bituminous minerals & $18,602.88$ & 11.79 \\
620 & Confectionery and sugar preparations, not chocolate & $13,178.75$ & 11.00 \\
712 & Extracts of coffee, essences and concentrates & $10,977.35$ & 9.85 \\
6645 & Glazed or cabled glass, in the form of rectangles & $13,704.9$ & 7.75 \\
\hline
\end{tabular}

Table 6 Distance $\left(\varphi_{i k}\right)$ of some products with regard to flowers and vehicles. Source: Author's calculations

\begin{tabular}{lrll}
\hline Motorcycles, auto-cycles; cars of all kinds, etc. & Cut flowers and foliage \\
\hline Chemical wood pulp, dissolving paste & 0.238 & Cotton seeds & 0.234 \\
Unroasted iron pyrites & 0.205 & $\begin{array}{l}\text { Minerals and concentrates of uranium and } \\
\text { thorium }\end{array}$ & 0.203 \\
Electric locomotives & 0.190 & Tea & 0.184 \\
Reclaimed leather, in plaques, sheets or rolls & 0.119 & Antibiotics, not put up as medicaments & 0.151 \\
Pianos and other string instruments & 0.066 & Pianos and other string instruments & 0.113 \\
Antibiotics, not put up as medicaments & 0.065 & Motorcycles, auto-cycles; cars of all kinds, etc. & 0.071 \\
\hline
\end{tabular}


Now, the density indicator can be estimated. Density and strategic value are two measures that, unlike PRODY, vary by country. That is, density, as a measure of distance from a product to the export basket of a country, is different according to the country. Therefore, Table 7 shows the 10 products closest to the export basket of Colombia. As can be seen in this table, the products that are closer to the production basket are of low sophistication. Most are natural resources without transformation. In fact, two of the ten products presented in Table 7 are part of the least sophisticated products in the world in 2014.

Finally, the strategic value indicator is calculated. This indicator takes both negative and positive values. A negative value of strategic value for a product means that including this product to the export basket of a country will diminish the value of new sophisticated production possibilities. A curious feature of this indicator is that it takes negative values for the most sophisticated products, because new sophisticated possibilities won't

Table 7 Ten products closest to the Colombian production basket. Source: Author's calculations

\begin{tabular}{lc}
\hline Product & Density \\
\hline Others carbon, not agglomerated & 0.169 \\
Mate & 0.163 \\
Palm almond oil & 0.161 \\
Palm oil & 0.145 \\
Copra (dry coconut pulp) & 0.139 \\
Minerals and concentrates of uranium and thorium & 0.137 \\
Sugar, beet and cane, raw, solid & 0.136 \\
Crude oil and oils obtained from bituminous minerals & 0.134 \\
Natural calcium phosphates, natural aluminum, etc. & 0.1332 \\
Fine cotton fibers & 0.1331
\end{tabular}

Table 8 "Best" 10 products for structural transformation in Colombia. Source: Author's calculations $^{\mathrm{a}}$

\begin{tabular}{lccc}
\hline Product & Strategic value standardized & Density & PRODY \\
\hline Sulfonamides & -0.061 & 0.105 & $50,092.77$ \\
Cellulose acetate & 1.025 & 0.100 & $34,717.73$ \\
Reaction motors & 0.237 & 0.102 & $37,686.39$ \\
Chemicals and flashlight materials for photography & 0.278 & 0.098 & $37,219.34$ \\
Crystals and parts of electronic components, not specified & 0.574 & 0.103 & $29,902.22$ \\
$\quad$ elsewhere & & & \\
Tin and its alloys worked & 0.188 & 0.110 & $27,271.03$ \\
X-ray apparatus and equipment; accessories and parts & -0.304 & 0.100 & $38,185.05$ \\
Glucosides, glands, antisera, vaccines and similar products & -0.785 & 0.097 & $43,439.2$ \\
Works of art, collectors' pieces and antiques & 0.770 & 0.095 & $31,560.09$ \\
Other organic-inorganic compounds & -0.044 & 0.092 & $38,512.07$
\end{tabular}

For this final table, only products with a PRODY of more than 20,000 (more than 20,000 dollars per capita) are considered. Only products with initial code 5, 6, 7 and 8, according to the SITC, which refer to chemical products, manufactured articles, machinery and equipment of transport and several manufactures, respectively, are taken. To determine the "best," we took the standardized value of $P R O D Y$, density and strategic value and we gave each one a weight of $1 / 3$. These values were added and organized from highest to lowest. The table shows uniquely the top 10 products 
now take into account these products. In order to avoid lengthening, I only present the values of strategic values for the "best" products.

Table 8 shows that the products that represent a better alternative for the sophistication of Colombian production are mainly chemical products (sulfonamides, cellulose acetate, chemical products for photography, glycosides and other compounds). In addition, they are the ones that have a higher PRODY in all the sample. On the other hand, there also appear manufactures that have a long process of transformation such as the engines of reaction and X-ray apparatuses. These are the 10 manufactured products that represent a better alternative of specialization for the country and that, consistent with the idea of selective industrial policy, should be subjects of state support.

The "best" products that were obtained, except works of art, are intermediate goods and not final consumer goods. Intermediate goods are, by definition, the best in terms of backward and forward linkages. They use more basic goods for their elaboration, thus promoting the development of such sectors, but they also allow the emergence of more advanced industrial sectors, which use them as inputs for the production of more sophisticated goods. "Linkages between firms through intermediate goods deliver a multiplier similar to the one associated with capital accumulation in a neoclassical growth model" (Jones 2008, p. 1). According to Jones (2008), production of intermediate goods is, in fact, fundamental in explaining the huge differences in per capita income that present in the world nowadays (50-fold differences).

\section{Conclusions}

Industrialization, as structural transformation of economies, has been the most successful vehicle for the development of nations in the world. In other words, industrialization is the process that explains differences in per capita incomes around the world. Nevertheless, Colombia' manufacturing sector has been plummeting in the last 25 years.

Manufacturing is a sector with peculiar characteristics that make it special to boost the advance of production of a country. On the one hand, manufacturing presents increasing returns, which are not present in other sectors of the economy. On the other, productivities in the manufacturing sector show unconditional convergence; that is, sectors that start with lower productivity grow faster, merging progressively to their technological frontiers.

Exploiting these potentialities of manufacturing requires statewide impetus. This impulse is also justified by the market failures that impede the development of industrial activities, even more when the development of the sector is rooted in innovation, or absorption of scientific and technological advances. It is required, then, to pursue an aggressive selective industrial policy. In this sense, a selective industrial policy that "chooses winners" and that "get the prices wrong," an industrial policy that counteracts the static efficiency of the free market. As Hausmann and Rodrik (2006) say, we are "doomed to choose."

But what has Colombia done in the last 25 years? Colombia adopted the Washington Consensus as a policy recipe with the so-called Apertura Económica and in particular entered into a process of trade liberalization (lower tariffs). This process of reform in Colombia, codified in the Consensus, was also experienced by the rest of the countries in the region (Lora 2012). 
This paper establishes an empirical exercise to determine possible causes of deindustrialization in Colombia, Brazil, Ecuador, Chile, Uruguay, Bolivia, Mexico, Costa Rica and Argentina. Thus, it is concluded that deindustrialization of the region is related, in order of importance, first, with the fall in tariffs (on account of the Consensus); second, with the increase in foreign direct investment flows; third, with a Dutch disease phenomenon, expressed through the significance of the participation of mining and energy exports and the appreciation of the real exchange rate; and fourth, to a lesser extent, with secular economic growth (as a normal process of transition to service economies). Therefore, the evidence provided in this paper is consistent with the idea that Colombia, together with other seven countries in Latin America, is deindustrializing prematurely.

The theory and evidence above lead to the need to give a turn to the policy on industrial development in Colombia, in particular, to establish a policy of state promotion of manufacturing. Based on the product space methodology (Hausmann and Klinger 2006; Hausmann et al. 2006), this paper also provides the strategic sectors for the Colombian State to promote, in order to achieve structural transformation. Those strategic sectors are, in general, intermediate goods that allow productive chains and, in particular, the chemical industry.

This work, then, is an exhortation to change the way of thinking industrial policy in Colombia. The idea is to move from a conception according to which "the best industrial policy is to have none" (Ocampo and Martínez 2011) to an industrial policy of state intervention in the promotion of strategic manufacturing sectors. This intervention appeals to policy instruments such as: subsidies and trade protectionism, state purchases and statewide collusion, among others. According to Rodrik, "a government that makes no mistakes when promoting industry is one that makes the bigger mistake of not trying hard enough" (Rodrik 2010). However, the most important thing is to change the government's attitude toward industrial development, that is, to declare the end of the Washington Consensus on industrial policy.

\section{Additional files}

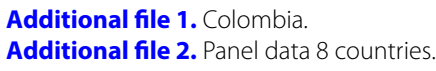

\section{Acknowledgements}

I want to thank the advice I received from David Bardey and Darío Maldonado, professors at the Universidad de Los Andes, in the elaboration of the first version of this paper. I also thank the valuable comments of three anonymous reviewers.

Competing interests

The author declares that he has no competing interests.

Availability of data and materials

The dataset supporting the conclusions of this article is included within the article and its additional files.

Consent for publication

Not applicable.

Ethics approval and consent to participate

Not applicable.

Funding

This research did not receive any specific grant from funding agencies in the public, commercial, or non-profit sectors. 


\section{Appendix 1}

The $p$ values obtained for the test applied in levels allow to conclude statistically that neither series are stationary (their tendency are clear). In addition, because of the test results in the first difference, it is concluded that both series have a unit root of order one. On the other hand, after a simple regression between manufacturing share and the average effective tariff, the errors of this relationship are predicted. Then, a DickeyFuller test is applied to these predicted errors to test their stationarity. The $p$ value obtained is 0.0751 , which indicates that, with a confidence interval of $90 \%$, the set of predicted errors is stationary. To ensure this, the Johansen test for cointegration is applied.

From Tables 9 and 10, it can be concluded that, with a 95\% confidence interval, there is cointegration between the series of interest and this is of rank 1. So, the OLS regression makes sense and there is a long-term relationship between the average effective tariff and the manufacturing share.

Table 9 Dickey-Fuller test. Source: Author's calculations

\begin{tabular}{lll}
\hline Variable & Levels & First differences \\
\hline Manufacturing/GDP & $p$ value $=0.951$ & $p$ value $=0.0000$ \\
AET & $p$ value $=0.6557$ & $p$ value $=0.0000$ \\
\hline
\end{tabular}

Table 10 Johansen test. Source: Author's calculations

\begin{tabular}{|c|c|c|c|c|c|}
\hline \multicolumn{3}{|c|}{ Constant tendency } & \multicolumn{3}{|c|}{ Observations $=43$} \\
\hline \multicolumn{3}{|c|}{ Sample: 1972-2014 } & \multicolumn{3}{|l|}{ Lags $=2$} \\
\hline Maximum range & Parameters & LL & Eigenvalue & Statistical & Values \\
\hline 0 & 6 & -157.11589 & & 16.2782 & 15.41 \\
\hline 1 & 9 & -148.9774 & 0.31514 & $0.0012^{*}$ & 3.76 \\
\hline 2 & 10 & -148.97681 & 0.00003 & & \\
\hline
\end{tabular}

\section{Appendix 2}

The Hausman test allows to verify the difference between the coefficients estimated by the fixed effects method and by random effects. If systematically different, estimation, in order to avoid bias, must be done using the fixed effects method. From Table 11, we conclude that the null hypothesis of the test must be rejected, and therefore, the estimation must be done with fixed effects. 
Table 11 Hausman test. Source: Author's calculations

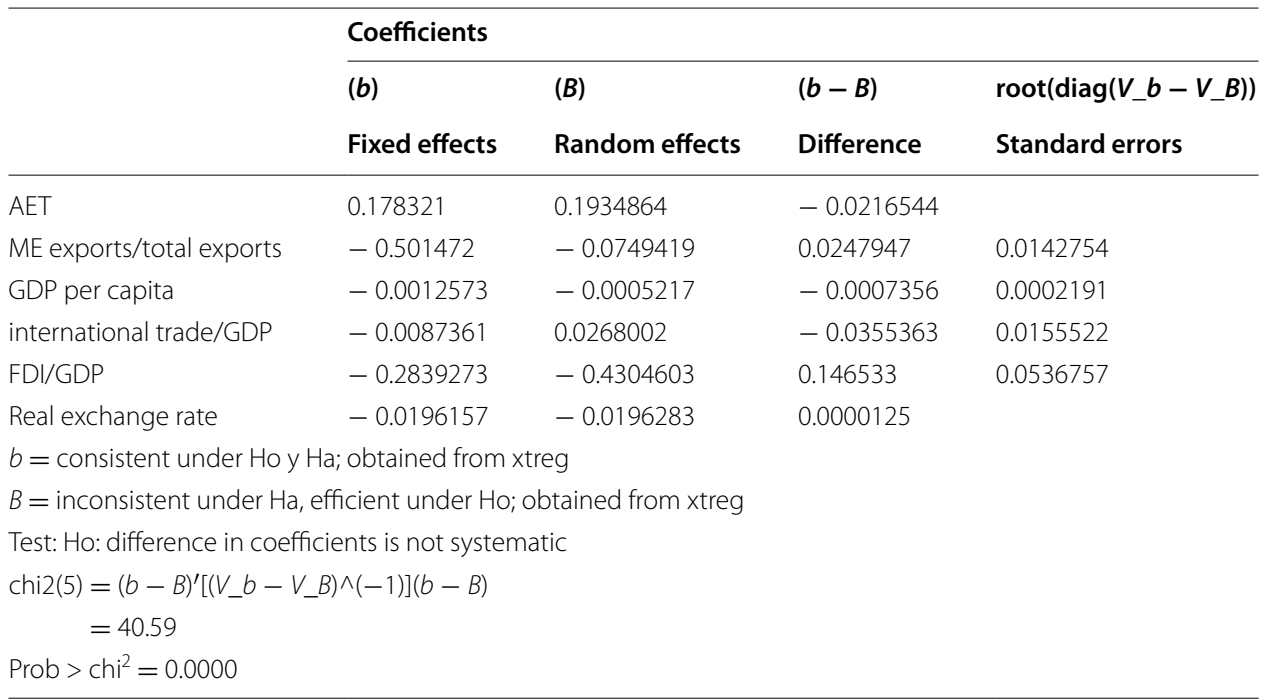

\section{Appendix 3}

With the exclusion of the variable of mining and energy exports and the inclusion of the share of basic exports, results change. The impact of FDI flows is reduced, while the impact of the AET remains practically the same. This result ratifies that, despite establishing some control by the factor endowment of each country, the AET remains the most relevant variable in relation to deindustrialization. Curiously, the share of basic exports doesn't show any significance.

Using most favored nation tariffs to instrument our variable of interest (i.e., average effective tariff rates) results ratify the significance and importance of AET explaining manufacturing participation. While the FDI variable loses significance, the coefficient of AET turns bigger. GDP per capita is still significant, which means that secular deindustrialization is part of the story. Mining and energy exports keep being significant, so the existence of a Ditch disease phenomenon is not discarded.

Finally, two additional variables are included: domestic credit to the private sector as a percentage of the GDP and the Net Barter Terms of Trade Index $(2000=100)$. This last model also reveals important changes in the significance of some variables. Although FDI remains significant, now mining and energy exports lose significance. Differences of significance of these two variables across different models indicate that these two are not very strong predicting the manufacturing performance. On the contrary, GDP per capita remains significant and at a $1 \%$ level, which means that it is not possible to reject that part of deindustrialization in the region is explained also by a secular process. Finally, AET remains significant and in absolute terms important explaining manufacturing participation.

These three additional robustness tests ratify that the AET is an important economic factor related to deindustrialization in Latin America (Table 12). 
Table 12 Robustness checks

\begin{tabular}{|c|c|c|c|}
\hline \multirow[t]{2}{*}{ Variables } & $\begin{array}{l}\text { (1) } \\
\text { Within with IV-basic } \\
\text { exports }\end{array}$ & $\begin{array}{l}\text { (2) } \\
\text { Within with IV (MFN tariff) }\end{array}$ & $\begin{array}{l}\text { (3) } \\
\text { Within with IV- } \\
\text { additional variables }\end{array}$ \\
\hline & Manufacturing/GDP & Manufacturing/GDP & Manufacturing/GDP \\
\hline AET & $\begin{array}{l}0.216^{* * *} \\
(0.0260)\end{array}$ & $\begin{array}{l}0.335^{* * *} \\
(0.0622)\end{array}$ & $\begin{array}{l}0.192^{* * *} \\
(0.0322)\end{array}$ \\
\hline ME exports/total exports & & $\begin{array}{l}-0.0652^{* * *} \\
(0.0240)\end{array}$ & $\begin{array}{l}-0.0134 \\
(0.0230)\end{array}$ \\
\hline GDP per capita & $\begin{array}{l}-0.000865^{* * *} \\
(0.000270)\end{array}$ & $\begin{array}{l}-0.00110^{* * *} \\
(0.000351)\end{array}$ & $\begin{array}{l}-0.00108^{* * *} \\
(0.000288)\end{array}$ \\
\hline International trade/GDP & $\begin{array}{l}(0.0157) \\
-0.0303\end{array}$ & $\begin{array}{l}0.0250 \\
(0.0264)\end{array}$ & $\begin{array}{l}-0.0194 \\
(0.0210)\end{array}$ \\
\hline $\mathrm{FDI} / \mathrm{GDP}$ & $\begin{array}{l}-0.188^{*} \\
(0.105)\end{array}$ & $\begin{array}{l}-0.131 \\
(0.0985)\end{array}$ & $\begin{array}{l}-0.234^{* *} \\
(0.101)\end{array}$ \\
\hline Real exchange rate & $\begin{array}{l}-0.0882^{* * *} \\
(0.0157)\end{array}$ & $\begin{array}{l}-0.0338^{*} \\
(0.0197)\end{array}$ & $\begin{array}{l}-0.0785^{* * *} \\
(0.0156)\end{array}$ \\
\hline$\%$ of basic exports & $\begin{array}{l}-0.0177 \\
(0.0189)\end{array}$ & & \\
\hline Terms of Trade Index & & & $\begin{array}{l}-0.0163 \\
(0.0101)\end{array}$ \\
\hline Domestic credit (\% GDP) & & & $\begin{array}{l}0.0392^{* * *} \\
(0.0119)\end{array}$ \\
\hline Constant & $\begin{array}{l}30.17^{* * *} \\
(1.799)\end{array}$ & $\begin{array}{l}23.01^{* * *} \\
(2.178)\end{array}$ & $\begin{array}{l}30.24^{* * *} \\
(1.778)\end{array}$ \\
\hline Observations & 229 & 167 & 225 \\
\hline$R^{2}$ & & 0.551 & 0.587 \\
\hline Countries & 8 & 8 & 8 \\
\hline
\end{tabular}

Standard errors in parenthesis

${ }^{* * *} p<0.01 ;{ }^{* *} p<0.05 ;{ }^{*} p<0.1$

\section{Appendix 4}

The selection of the following industrial policy tools was developed by Ha-Joon Chang (2010), based on the experience of Asian tigers (mainly Japan and Korea). It is presented in order to understand the policy measures to which this work refers. It is important to remember that these measures are to be used in a selective way, to potentiate particular economic sectors.

1. Subsidies and trade protectionism.

2. Coordination of complementary investments.

3. Regulation to the entry of new firms.

4. State purchases and collusions through the State, to guarantee economies of scale.

5. Regulation on technological imports, such as unrestricted access to imported technology.

6. Regulation of FDI (restrictions on entry and ownership, local content requirements, technological transfer requirements, etc.).

7. State as capitalist and as an investor in risky activities.

8. Promotion of exports, through subsidies, access to cheap credits, etc.

9. Promotion of importation of capital goods. 


\section{Publisher's Note}

Springer Nature remains neutral with regard to jurisdictional claims in published maps and institutional affiliations.

Received: 19 May 2017 Accepted: 27 October 2017

Published online: 06 November 2017

\section{References}

Amsden A (1991) The late-industrializing model and Greater East Asia. Am Econ Rev 28:282-286

Amsden A (1992) Corea, un proceso exitoso de industrialización tardía. Norma, Santafé de Bogotá

Aubert C, Falck O, Heblich S (2011) Subsidizing national champions: an evolutionary perspective. In: Falck O, Gollier C, Woessm L (eds) Industrial policy for national champions. The MIT Press, Cambridge, pp 63-88

Banco Mundial (2016) World development indicators. Obtained from the website of the World Bank: http://data.worldbank.org/data-catalog/world-development-indicators

Bárcena A (2015) Lecciones aprendidas de la IED en América Latina y el Caribe. Obtained from the ECLAC website: http:// www.cepal.org/sites/default/files/presentation/files/150428_25anos_de_ied_en_alc_ultimaversion.pdf

Beck N, Katz J (1995) What to do (and not to do) with time-series cross-section data. The American Political Science Review 89:634-647

Bogliaccini JA (2013) Trade liberalization, deindustrialization, and inequality. Lat Am Res Rev 48:79-105

Chang H-J (1994) The political economy of industrial policy. Palgrave Macmillan, London

Chang H-J (2010) Industrial policy: can we go beyond an unproductive confrontation? Turkish Economic Association

Chang H-J, Andreoni A (2016) Industrial policy in a changing world: basic principles, neglected issues and new challenges. In: Cambridge Journal of Economics 40 years conference

Clavijo S, Vera A, Fandiño A (2012) La desindustrialización en Colombia: análisis cuantitativo de sus determinantes. ANIF, Bogotá

DIAN (2016) Respuesta a solicitud de información con radicado No. 000E2016003324 del 11 de febrero de 2016. Bogotá

Felipe J, Mehta A, Rhee C (2014) Manufacturing matters... But it's Jobs that Count. ADB Economics, Working paper series no. 420

Hausmann R, Klinger B (2006) Structural transformation and patterns of comparative advantage in the product space. Working paper series, Harvard University, John F. Kennedy School of Government

Hausmann R, Rodrik D (2006) Doomed to choose: industrial policy as predicament. John F. Kennedy School of Government, Cambridge

Hausmann R, Hwang J, Rodrik D (2006) What you export matters. NBER working paper series

Jones C (2008) Intermediate goods, weak links and superstars: a theory of economic development. NBER working paper series

Johnson C (1982) MITI and the Japanese Miracle: the growth of industrial policy, 1925-1975. Stanford, California: Stanford University Press.

Lin J, Chang H-J (2009) Should industrial policy in developing countries conform to comparative advantage or defy it? A debate between Justin Lin and Ha-Joon Chang. Dev Policy Rev 27:483-502

Lora E (2012) Las reformas estructurales en América Latina: Qué se ha reformado y cómo medirlo. Documento de trabajo del BID

Marconi N, de Borja Froés, Reis C, de Araújo EC (2016) Manufacturing and economic development: the actuality of Kaldor's first and second laws. Struct Change Econ Dyn 37:75-89

Mayer W (1984) Endogenous tariff formation. Am Econ Rev 74:970-985

Montero R (2013) Variables no estacionarias y cointegración. Documentos de Trabajo de Economía Aplicada, Universidad de Granada, España

Ocampo JA, Martínez A (2011) Hacia una Política Industrial de nueva generación en Colombia. Coalición para la promoción de la industria colombiana, Bogotá

Parker J (2015) Distributed-lag models. Obtained from Reed College website: http://www.reed.edu/economics/ parker/312/tschapters/S13_Ch_3.pdf

Petreski M, Jovanovic B, Velickovski I (2015) Tariff induced (de)industrialization: an empirical analysis. Munchen Personal RePEc Archive

Reinert E (2007) How rich countries got rich and why poor countries stay poor. Public Affairs, London

Rodrik D (2008) Industrial policy: don't ask why, ask how. Middle East Dev J 1:1-29

Rodrik D (2010) The return of industrial policy. Obtained from Project Syndicate website: http://www.project-syndicate. org/commentary/the-return-of-industrial-policy

Rodrik D (2013a) The past, present and future of economic growth. Global Citizen Foundation, London

Rodrik D (2013b) Unconditional convergence in manufacturing. Q J Econ 128:165-204

Rodrik D (2014) Are services the new manufactures? Obtained from Project Syndicate website: http://www.projectsyndicate.org/commentary/are-services-the-new-manufactures-by-dani-rodrik-2014-10

Rodrik D (2015a) Back to fundamentals in emerging markets. Obtained from Project Syndicate website: http://www. project-syndicate.org/commentary/emerging-market-growth-by-dani-rodrik-2015-08

Rodrik D (2015b) Premature deindustrialization. IAS economics working papers

Rosiak-Lada K, Wójcik P (2006) Dynamic models: notes of class. Obtained from the University of Warsaw website: http:// www.ekonometria.wne.uw.edu.pl/uploads/Main/3.pdf

Rowthorn R (1997) Deindustrialization: causes and implications. IMF working paper

Stiglitz J, Greenwald B (2013) Industrial policies, the creation of a learning society, and economic development. In: Stiglitz J, Lin J (eds) The industrial policy revolution I: the role of government beyond ideology. Palgrave Macmillan, London, pp 43-72 
Stiglitz JE, Lin J, Monga C (2013) The rejuvenation of industrial policy. Policy research working paper, The World Bank UNCTAD (2016) Trade and development report, 2016: structural transformation for inclusive and sustained growth. United Nations, New York

Wade R (1990) Governing the market: economic theory and the role of government in East Asian industrialization. Princeton University Press, Princeton

Williamson J (1990) What Washington means by policy reform. In: Williamson J (ed) Latin American adjustment: how much has happened. Institute for International Economics, Washington, pp 7-20

World Bank (2010) Types of tariffs. Obtained from the World Integrated Trade Solution website of the World Bank: https:// wits.worldbank.org/wits/wits/witshelp/content/data_retrieval/p/intro/c2.types_of tariffs.htm

World Bank (2013) Online trade outcomes indicators. Obtained from the World Integrated Trade Solution website, by The World Bank: http://wits.worldbank.org/WITS/docs/TradeOutcomes-UserManual.pdf

Submit your manuscript to a SpringerOpen ${ }^{\circ}$ journal and benefit from:

Convenient online submission

Rigorous peer review

Open access: articles freely available online

- High visibility within the field

- Retaining the copyright to your article

Submit your next manuscript at $\boldsymbol{\nabla}$ springeropen.com 